\title{
TINJ AUAN KETEPATAN KODE DIAGNOSIS CEDERA DAN PENYEBAB LUAR CEDERA (EXTERNAL CAUSES) PASIEN RAWAT INAP DI RUMAH SAKIT ISLAM "SITI HAJAR" MATARAM
}

\author{
Ikhwan' ${ }^{1}$, Syamsuriansyah², M uhammad M akmur Purna I rawan ${ }^{3}$ \\ 1, 2, 3. Program Studi R ekam M edis dan Informasi Kesehatan, Politeknik M edica Farma H usada M ataram \\ E mail: sam_bptk@yahoo.com
}

\begin{abstract}
The research objective was to determine the accuracy of the diagnosis code and cause injury beyond the injury inpatients based on ICD-10. This type of research is descriptive with the approach of retrospective study was conducted at the Islamic Hospital Siti Hajar Mataram June 50, 2014. The sample size medical record file is retrieved with non-randomtechniques sampling.Pengumpul an data by observation. Data wereanalyzed descriptively. Hasill research shows that 3 codeinaccurateand accurate code 47 and 41 external causecodeis not written and 9 injuries injury diagnosis on medical record file is written not cause outward. Inaccuracy injury diagnosis codes on entry and exit summary form patients consisted of error election Block, Sub-digit bl ocks and errors on the 4th and 5th.
\end{abstract}

Keymords: accuracy code, Injury, external causes

\begin{abstract}
A bstrak
Tujuan penelitian ini adalah mengetahui ketepatan kodediagnosis cedera dan penyebab luar cedera pasien rawat inap berdasarkan ICD-10.J enis penelitian ini adal ah deskriptif dengan dengan pendekatan retrospektifPenelitian dilakukan di Rumah Sakit I slam Siti Hajar Mataram pada J uni 2014. Besar sampe 50 berkas rekam medis yang diambil dengan teknik non random sampling.Pengumpulan data dengan cara observasi. Data dianal isis secara deskriptif. Hasill penelitian menunjukkan bahwa 3 kodetidak akurat dan 47 kodeakurat Dan 41 kode penyebab luar cedera tidak ditulis dan 9 di agnosis cedera pada berkas rekam medis tidak ditulis penyebab luarnya. Ketidaktepatan kode diagnosis cedera pada formulir ringkasan masuk dan keluar pasien terdiri dari kesal ahan pemilihan Blok, Sub bl ok dan kesalahan pada digit ke-4 dan ke-5.
\end{abstract}

Kata K unci: ketepatan kode, Cedera, penyebab luar

\section{PE NDAHUL UAN}

Tujuan rekam medis adalah untuk menunjang tercapai nya tertib administrasi dalam rangka upaya peningkatan pelayanan kesehatan di Rumah Sakit. Tanpa dukungan suatu sistem pengelolaan rekam medis yang baik dan benar, maka tertib administrasi di RumahSakittidak akan berhasil sebagaimanayang diharapkan (Rustiyanto, 2011)

Agar tercapainya tertib administrasi dibutuhkan tenaga medis yang mampu memberikan informasi secara tepat dan lengakap mengenai diagnosa utama serta penyebabluar penyakit pasien (exsternal cause) yang ditul is secarajelas didalamberkas rekammedis (Riyadina dan Subik, 2007).
Petugas koding harus mampu menentukan kode ICD-10 (International Statistical Classification of Diseases Related Health Problems Tenth Revision) diagnosis utama pasien dan kode penyebab luar (external causes) yang tercatat dalam dokumen rekam medis pasien secara tepat.Diagnosis utama adalah jenis penyakit utama yang diderita pasien setel ah dilakukan pemeriksaan yang lebi $\mathrm{h}$ mendal am Diagnosis utama dilihat pada formulir ringkasan masuk dan keluar, sedangkan penyebab luar (external causes) dapat dilihat dilembar anamnase atau diformul ir khusus pasien gawat darurat (emergency) (Budi, 2011).

Hasil koding selanjutnya akan digunakan sebagai acuan petugas rekammedis untuk mengelompokkan 
diagnosis pasien tersebut dalam kartu indeks penyakit. Kartu indeks penyakit inilah yang akan digunakan untuk menghitung berbagai angkastatistik Rumah Sakit atau menelusuri data dan informasi tentang diagnosistertentu untuk berbagai keperluan. A pabila dalammengode di agnosis tidak tepat maka dalam pembuatan laporan morbiditas, mortalitas serta penghitungan berbagai angka statistik Rumah Sakit akan salah atau tidak tepat. Tujuan penelitian adalah untuk mengetahui ketepatan kode dan faktor penyebab tidak tepat kodefikasi berdasarkanICD-10 pada diagnosis cedera dan penyebab luar cedera (external cause) pada pasien rawat inap.

\section{METODE}

Rancangan penelitian adalah deskriptif dengan pendekatan retrospektif (Dharma, 2011: 72), di Rumah Islam "Siti Hajar" MataramRumah Sakit Islam "Siti Hajar" Mataram pada J uni 2014.Teknik non random sampling yang digunakan adalah purposive sampling dengan sampel berjumlah 50 berkas rekam medis. Pengumpul an data dengan metode observasi, wawancara dan dokumentasi . Pengolahan dan analisa data dengan Pengumpulan (Collecting), Klasifikasi (Classification), Tabulasi (Tabulating) dan narasi, serta dianalisis secara deskriptif.

\section{HASIL}

Jumlah kode diagnosis cedera yang tepat 3 kode dan yang tidak tepat 47 kode dari 50 kode diagnosis cedera sedangkan jumlah penyebab luar cedera dari 50 diagnosis cedera adal ah 41, artinya tidak semua diagnosis cedera ditulis atau dilengkapi dengan informasi penyebab luar cedera (external cause).Dari 41 jumlah penyebab luar ini tidak dikode sehingga tidak dapat diverifikasi ketepatanya (Tabel 1).

Tabel 1. Ketepatan Kode Diagnosis Cedera dan Penyebab Luar Cedera Secara Umum

\begin{tabular}{|c|c|c|c|c|c|c|c|}
\hline \multirow{2}{*}{ No } & \multirow{2}{*}{$\begin{array}{l}\text { Klasifikasi } \\
\text { TipeCedera }\end{array}$} & \multirow{2}{*}{$\sum \mathbf{K}$} & \multicolumn{2}{|c|}{$\begin{array}{l}\text { K ode Diagno- } \\
\text { sis C edera }\end{array}$} & \multicolumn{3}{|c|}{$\begin{array}{l}\text { K ode Penyebab } \\
\text { L uar }\end{array}$} \\
\hline & & & $T$ & TT & $\begin{array}{l}\sum_{\text {bab L uar }} \text { Penye- } \\
\text { lab }\end{array}$ & $T$ & $\overline{T T}$ \\
\hline 1 & $\begin{array}{l}\text { Cedera } \\
\text { permukaan } \\
\text { (Superfisial } \\
\text { injury) }\end{array}$ & 2 & - & 2 & 1 & - & - \\
\hline 2 & $\begin{array}{l}\text { LukaTerbuka } \\
\text { (Open } \\
\text { Wound) }\end{array}$ & 3 & 1 & 2 & 3 & - & - \\
\hline
\end{tabular}

\begin{tabular}{llllllll}
\hline 3 & $\begin{array}{l}\text { Patah tul ang } \\
\text { (Fracture) }\end{array}$ & 22 & 0 & 22 & 17 & - & - \\
\hline 4 & $\begin{array}{l}\text { Terpisah dari } \\
\text { Lokasinya } \\
\text { (Dislokasi) }\end{array}$ & 8 & 2 & 6 & 5 & - & - \\
\hline 5 & $\begin{array}{l}\text { Cedera Organ } \\
\text { Bagian } \\
\text { Dalam } \\
\text { (Internal }\end{array}$ & 15 & 0 & 15 & 15 & - & - \\
& & & & & & & \\
Injury) & & & & & & & \\
\hline J umlah & $\mathbf{5 0}$ & $\mathbf{3}$ & $\mathbf{4 7}$ & $\mathbf{4 1}$ & - & - \\
\hline
\end{tabular}

Keterangan:

T: Tepat TT: Tidak Tepat

Kode diagnosis cedera permukaan (Superficial Injury)tidak adayang tepat, kesalahan ada pada kategori Blok dan diagnosis sekunder tidak di kode sebanyak 1 kasus dan 1 kode di git ke-4 (Tabel 2).

1. Tinjauan K etepatan K ode Diagnosis C edera

a. Tipe Cedera Permukaan (Superficial Injury)

Tabel 2. K etepatan K ode Diagnosis C edera

\begin{tabular}{|c|c|c|c|c|c|c|c|}
\hline \multirow{2}{*}{ No } & \multirow{2}{*}{$\begin{array}{l}\text { Diagnosis } \\
\text { Cedera }\end{array}$} & \multirow{2}{*}{$\sum \mathrm{K}$} & \multicolumn{2}{|c|}{ Kode Diagnosis } & \multicolumn{2}{|c|}{$\begin{array}{l}\text { K tptn } \\
\text { K o }\end{array}$} & \multirow{2}{*}{$\begin{array}{l}\text { K ete- } \\
\text { rangan }\end{array}$} \\
\hline & & & $R M \& K$ & $\begin{array}{l}\text { Sesuai } \\
\text { ICD }\end{array}$ & $T$ & TT & \\
\hline 1 & Hematoma & 1 & T14 & T14.0 & - & 1 & $\begin{array}{l}\text { Kesalahan } \\
\text { pada digit } \\
\text { ke-4 }\end{array}$ \\
\hline 2 & $\begin{array}{l}\text { Combustion } \\
\text { tingkat II } \\
\text { tangan atas } \\
9 \% \text { badan } \\
18 \% \text { + dada }\end{array}$ & 1 & T30 & $\begin{array}{l}\text { T00.8 } \\
\text { T23.2 } \\
\text { T21.2 }\end{array}$ & - & 1 & $\begin{array}{l}\text { Kategori } \\
\text { kesal ahan } \\
\text { pada } \\
\text { Blok dan } \\
\text { diagnosis } \\
\text { sekunder } \\
\text { tidak di } \\
\text { kode }\end{array}$ \\
\hline um & & 2 & & & 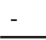 & 2 & \\
\hline
\end{tabular}

Keterangan:

T: Tepat TT: Tidak Tepat

Kode diagnosis cedera luka terbuka (open wound) yang tepat 1 kode sedangkan yang tidak tepat 2 kodeyaitu kesalahan ada pada kategori blok sebanyak 2 kode dan tidak memberi kodediagnosissekunder (Tabel 3).

b. Tipe Cedera Open Wound (luka terbuka)

Tabel 3. Ketepatan Kode Diagnosis

\begin{tabular}{|c|c|c|c|c|c|c|c|}
\hline \multirow[t]{2}{*}{ No } & \multirow[t]{2}{*}{$\begin{array}{l}\text { Diagnosis } \\
\text { Cedera }\end{array}$} & \multirow[t]{2}{*}{$\sum$} & \multicolumn{2}{|c|}{ Kode Diagnosis } & \multicolumn{2}{|c|}{$\begin{array}{l}\text { Ktptn } \\
\text { Ko }\end{array}$} & \multirow[t]{2}{*}{$\begin{array}{l}\mathrm{K} \text { e t e - } \\
\text { rangan }\end{array}$} \\
\hline & & & $\mathrm{RM} \& \mathrm{~S}$ & $\begin{array}{l}\text { Sesuai } \\
\text { ICD }\end{array}$ & $T$ & TT & \\
\hline$\overline{1}$ & $\begin{array}{l}\text { Lukarobek pada } \\
\text { kepala, vul nus } \\
\text { laceration }\end{array}$ & 1 & S32.8 & S01.9 & - & 1 & $\begin{array}{l}\text { Kategori } \\
\text { kesalahan } \\
\text { pada } \\
\text { Blok }\end{array}$ \\
\hline
\end{tabular}


J urnal Manajemen I nformasi Kesehatan Indonesia Vol . 4 No.2 Oktober 2016

ISSN: 2337-6007 (online); 2337-585X (Printed)

\begin{tabular}{|c|c|c|c|c|c|c|c|}
\hline 2 & $\begin{array}{l}\text { Luka bacok } \\
\text { pada tel apak } \\
\text { tangan, I uka } \\
\text { tusuk pada bahu }\end{array}$ & 1 & T14.6 & $\begin{array}{l}\text { S61.9 } \\
\text { S41.0 }\end{array}$ & - & 1 & $\begin{array}{l}\text { Kategori } \\
\text { kesalahan } \\
\text { pada } \\
\text { Blok dan } \\
\text { diagnosis } \\
\text { sekunder }\end{array}$ \\
\hline 3 & $\begin{array}{l}\text { L uka robek } \\
\text { padajari kaki }\end{array}$ & 1 & S91.1 & S91.1 & 1 & - & $\begin{array}{l}\text { Sesuai } \\
\text { aturan } \\
\text { ICD-10 }\end{array}$ \\
\hline \multicolumn{2}{|c|}{ J umlah } & 3 & & & 1 & 2 & \\
\hline
\end{tabular}

Keterangan:

T: Tepat TT: Tidak Tepat

Dari 22 jumlah kasus cedera patah tulang (fracture)tidak adayang tepat, kesalahan ada pada kategori blok sebanyak 3 kode, Kesalahan pada digit ke-4 dan digit ke-5 sebanyak 4 kode dan kesalahan digit ke 5 kelima15 kodesertadiagnosis sekundertidak dikode (Tabel 4).

c. Tipe Cedera Patah Tulang (Fracture) Tabel 4. Ketepatan Kode Diagnosis

\begin{tabular}{|c|c|c|c|c|c|c|c|}
\hline \multirow{2}{*}{ No } & \multirow{2}{*}{$\begin{array}{l}\text { Diagnosis } \\
\text { Cedera }\end{array}$} & \multirow{2}{*}{$\sum K$} & \multicolumn{2}{|c|}{ Kode Diagnosis } & \multicolumn{2}{|c|}{$\begin{array}{l}K+p t n \\
\text { Ko }\end{array}$} & \multirow{2}{*}{$\begin{array}{l}\mathrm{K} e \mathrm{t} \text { e } \\
\text { rangan }\end{array}$} \\
\hline & & & RM\&S & $\begin{array}{l}\text { Sesuai } \\
\text { ICD }\end{array}$ & $T$ & TT & \\
\hline 1 & Fr. Cruris & 3 & 582.2 & S82.20 & - & 3 & $\begin{array}{l}\text { Kesalahan } \\
\text { pada digit } \\
\text { ke-5 }\end{array}$ \\
\hline 2 & Fr. Clavicula dx & 1 & $\mathrm{~S} 82.2$ & 542.00 & - & 1 & $\begin{array}{l}\text { Kategori } \\
\text { kesalahan } \\
\text { pada Blok }\end{array}$ \\
\hline 3 & Fr. Clavicula & 1 & S12.9 & $\$ 42.00$ & - & 1 & $\begin{array}{l}\text { Kategori } \\
\text { kesa-lahan } \\
\text { pada Blok }\end{array}$ \\
\hline 4 & Fr. Femur & 1 & $S 72.9$ & $\mathrm{~S} 72.90$ & - & 1 & $\begin{array}{l}\text { kesalahan } \\
\text { pada digit } \\
\text { ke-5 }\end{array}$ \\
\hline 5 & $\begin{array}{l}\text { Fr. Femur dx } 1 / 3 \\
\text { distal }\end{array}$ & 1 & $S 72.9$ & $\mathrm{~S} 72.90$ & - & 1 & $\begin{array}{l}\text { kesalahan } \\
\text { pada digit } \\
\text { ke-5 }\end{array}$ \\
\hline 6 & $\begin{array}{l}\text { Fr. Distal } \\
\text { femur }\end{array}$ & 1 & S72.4 & 572.40 & - & 1 & $\begin{array}{l}\text { kesalahan } \\
\text { pada digit } \\
\text { ke-5 }\end{array}$ \\
\hline 7 & $\begin{array}{l}\text { Fr. Humerus } \\
\text { proksimal }\end{array}$ & 1 & 542.2 & 542.20 & - & 1 & $\begin{array}{l}\text { kesalahan } \\
\text { pada digit } \\
\text { ke-5 }\end{array}$ \\
\hline 8 & Fr. Humerus & 1 & S42.3 & 542.30 & - & 1 & $\begin{array}{l}\text { kesalahan } \\
\text { pada digit } \\
\text { ke-5 }\end{array}$ \\
\hline 9 & Fr. HumerusDx & 1 & S42.3 & 542.30 & - & 1 & $\begin{array}{l}\text { kesalahan } \\
\text { pada digit } \\
\text { ke-5 }\end{array}$ \\
\hline 10 & $\begin{array}{l}\text { Fr. Froxsimal } \\
\text { humerus dextra }\end{array}$ & 1 & S42 & 542.20 & - & 1 & $\begin{array}{l}\text { Kesalahan } \\
\text { pada digit } \\
\text { ke- } 4 \text { dan } \\
\text { digit ke-5 }\end{array}$ \\
\hline
\end{tabular}

\begin{tabular}{|c|c|c|c|c|c|c|c|}
\hline 11 & $\begin{array}{l}\text { Closed globe } \\
\text { injury + fr. } \\
\text { Humerus, skin } \\
\text { loss luasregion } \\
\text { b r a c h i / } \\
\text { antebrachi }\end{array}$ & 1 & 542.3 & $\begin{array}{l}\text { S05.9 } \\
\text { S42.3.0 } \\
\text { T50.9 }\end{array}$ & - & 1 & $\begin{array}{l}\text { Kesalahan } \\
p \text { a d a } \\
\text { digit ke-5 } \\
\text { dan tidak } \\
\text { mengkode } \\
\text { diagnosis } \\
\text { sekunder }\end{array}$ \\
\hline 12 & $\begin{array}{l}\mathrm{Fr} . \quad \text { De n to } \\
\text { Alveolus rahang } \\
\text { atas }\end{array}$ & 2 & S02.5 & S02.70 & - & 2 & $\begin{array}{l}\text { Kesalahan } \\
\text { pada digit } \\
\text { ke-4 dan } \\
\text { digit ke-5 }\end{array}$ \\
\hline 13 & $\begin{array}{l}\text { Fr. Dentoalveolus } \\
+ \text { fr. Colles }\end{array}$ & 1 & S92.5 & $\begin{array}{l}\mathrm{S} 02.80 \\
\mathrm{~S} 52.50\end{array}$ & - & 1 & $\begin{array}{l}\text { Kesalahan } \\
\text { pada Blok } \\
\text { dan Tidak } \\
\text { mengkode } \\
\text { diagnosis } \\
\text { sekunder }\end{array}$ \\
\hline 14 & Fr. Ulna & 1 & S52.2 & 552.20 & - & 1 & $\begin{array}{l}\text { kesalahan } \\
\text { pada digit } \\
\text { ke-5 }\end{array}$ \\
\hline 15 & $\begin{array}{l}\text { Fr. Radius } \\
\text { ulna tangan } \\
\text { kiri }\end{array}$ & 1 & S52.9 & S52.70 & - & 1 & $\begin{array}{l}\text { Kesalahan } \\
\text { pada digit } \\
\text { ke-4 dan } \\
\text { digit ke-5 }\end{array}$ \\
\hline 16 & Fr. Foot & 1 & 592.9 & S92.90 & - & 1 & $\begin{array}{l}\text { kesalahan } \\
\text { pada digit } \\
\text { ke-5 }\end{array}$ \\
\hline 17 & Fr. Pelvis & 1 & S32.8 & S32.80 & - & 1 & $\begin{array}{l}\text { kesalahan } \\
\text { pada digit } \\
\text { ke-5 }\end{array}$ \\
\hline 18 & $\begin{array}{l}\text { Fr. Metacarval } \\
\text { manus sinistra } \\
\text { digit III }\end{array}$ & 1 & 562.3 & 562.60 & - & 1 & $\begin{array}{l}\text { kesalahan } \\
\text { pada digit } \\
\text { ke-5 }\end{array}$ \\
\hline 19 & Fr. Multipel & 1 & T02.9 & T02.90 & - & 1 & $\begin{array}{l}\text { kesalahan } \\
\text { pada digit } \\
\text { ke-5 }\end{array}$ \\
\hline \multicolumn{2}{|c|}{ Jumlah } & 22 & & & - & 22 & \\
\hline
\end{tabular}

Keterangan:

T: Tepat TT: Tidak Tepat

Kode diagnosis cedera kasus dislokasi yang tepat 2 kode sedangkan yang tidak tepat 5 kode kesal ahan ada pada kategori blok sebanyak lima kode, 1 kode kesalahan pada digit ke-4 dan kesalahan pada Sub blok 1 kode (Tabe 5).

d. Tipe Cedera Dislokasi

Tabel 5. Ketepatan Kode Diagnosis

\begin{tabular}{|c|c|c|c|c|c|c|c|}
\hline \multirow[b]{2}{*}{ No } & \multirow{2}{*}{$\begin{array}{l}\text { Diagnosis } \\
\text { Cedera }\end{array}$} & \multirow{2}{*}{$\frac{\mathrm{K}}{\sum}$} & \multicolumn{2}{|c|}{ KodeDiagnosis } & \multicolumn{2}{|c|}{$\begin{array}{l}\text { Ktptan } \\
\text { Ko }\end{array}$} & \multirow{2}{*}{ Keterangan } \\
\hline & & & RM\&S & $\begin{array}{l}\text { Sesuai } \\
\text { ICD }\end{array}$ & $T$ & Tा & \\
\hline 1 & $\begin{array}{l}\text { Dislokasi } \\
\text { panggul }\end{array}$ & 1 & S82.2 & S73.0 & - & 1 & $\begin{array}{l}\text { K ategori } \\
\text { kesal ahan } \\
\text { padaBlok }\end{array}$ \\
\hline 2 & $\begin{array}{l}\text { Dislokasi } \\
\text { panggul }\end{array}$ & 1 & T14.3 & S73.0 & - & 1 & $\begin{array}{l}\text { K ategori } \\
\text { kesal ahan } \\
\text { padaBlok }\end{array}$ \\
\hline 3 & $\begin{array}{l}\text { Dislokasi } \\
\text { joint }\end{array}$ & 1 & T14.3 & T14.3 & 1 & - & $\begin{array}{l}\text { Sesuai aturan } \\
\text { ICD-10 }\end{array}$ \\
\hline 4 & $\begin{array}{l}\text { Dislokasi } \\
\text { elbow }\end{array}$ & 1 & S53.4 & S53.1 & - & 1 & $\begin{array}{l}\text { Kesalahan pa } \\
\text { da digit ke-4 }\end{array}$ \\
\hline
\end{tabular}




\begin{tabular}{|c|c|c|c|c|c|c|c|}
\hline 5 & $\begin{array}{l}\text { Dislokasi } \\
\text { elbow }\end{array}$ & 1 & T14 & S53.1 & - & 1 & $\begin{array}{l}\text { Kategori } \\
\text { kesal ahan } \\
\text { padaBlok }\end{array}$ \\
\hline 6 & $\begin{array}{l}\text { Dislokasi } \\
\text { el bo w, } \\
\text { k a p u t } \\
\text { humerus } \\
\text { nyeri pada } \\
\text { sendi }\end{array}$ & 1 & S43.0 & S53.1 & - & 1 & $\begin{array}{l}\text { K ategori } \\
\text { kesal ahan } \\
\text { padaBlok }\end{array}$ \\
\hline 7 & $\begin{array}{l}\text { Dislokasi } \\
\text { t a I u s, } \\
\text { dislokasi } \\
\text { ankle }\end{array}$ & 1 & S92.1 & S93.0 & - & 1 & $\begin{array}{l}\text { Kesal ahan } \\
\text { padaSub blok }\end{array}$ \\
\hline 8 & $\begin{array}{l}\text { Dislokasi } \\
\text { femur }\end{array}$ & 1 & S73.0 & S73.0 & 1 & - & $\begin{array}{l}\text { Sesuai aturan } \\
\text { ICD-10 }\end{array}$ \\
\hline \multicolumn{2}{|c|}{ Jumlah } & 8 & & & 2 & 6 & \\
\hline
\end{tabular}

Keterangan:

T: Tepat TT: Tidak Tepat

Kode diagnosis cedera organ bagian dalam (internal injury)tidak adayang tepat, kesalahan ada pada digit ke-4 dan ke-5 sebanyak 8 kode kesalahan ada padaSub blok dengan diagnosis sekundertidak dikode 1 kasus, Digitke-4danke-5 dengan diagnosis sekunder tidak dikode 1 kasus dan 5 kodekesal ahan ada pada Sub kategori digit ke-5 (Tabel 6).

e Tipe Cedera Internal Injury

Tabel 6. Ketepatan Kode Diagnosis

\begin{tabular}{|c|c|c|c|c|c|c|c|}
\hline \multirow[b]{2}{*}{ No } & \multirow{2}{*}{$\begin{array}{l}\text { Diagnosis } \\
\text { Cedera }\end{array}$} & \multirow[b]{2}{*}{$\sum \mathrm{K}$} & \multicolumn{2}{|c|}{ Kode Diagnosis } & \multicolumn{2}{|c|}{$\begin{array}{l}\text { Ktptn } \\
\text { Ko }\end{array}$} & \multirow[b]{2}{*}{ - Keterangan } \\
\hline & & & $\overline{\mathrm{RM} \& \mathrm{~S}}$ & $\begin{array}{l}\text { Sesuai } \\
\text { ICD }\end{array}$ & $\mathbf{T}$ & $\overline{T T}$ & \\
\hline 1 & $\begin{array}{l}\text { C } \quad \mathrm{K} \quad \mathrm{R} \\
\text { (C eder a } \\
\text { K e p a I a } \\
\text { Ringan) }\end{array}$ & & S06.0 & S06.00 & - & 5 & $\begin{array}{l}\text { K esal ahan } \\
\text { tidak menam- } \\
\text { bahkan digit } \\
\text { ke5 }\end{array}$ \\
\hline 2 & CKR & 8 & S06 & S06.00 & - & 8 & $\begin{array}{l}\text { K esal ahan } \\
\text { pada digitke-4 } \\
\text { dan ke-5 }\end{array}$ \\
\hline 3 & $\begin{array}{l}\text { CKS + fr. } \\
\text { Femur }\end{array}$ & 1 & S06 & $\begin{array}{l}\text { S06.20 } \\
\text { S72.90 }\end{array}$ & - & 1 & $\begin{array}{l}\text { Kesal ahan } \\
\text { pada digit } \\
\text { ke-4 dan ke-5 } \\
\text { + diagnosis } \\
\text { sekundertidak } \\
\text { di kode }\end{array}$ \\
\hline 4 & $\begin{array}{l}\text { CKR + fr. } \\
\text { Orbita }\end{array}$ & 1 & S02.4 & $\begin{array}{l}\text { S06.00 } \\
\text { S02.90 }\end{array}$ & - & 1 & $\begin{array}{l}\text { Salah pada } \\
\text { Sub blok + } \\
\text { di agnosis } \\
\text { sekundertidak } \\
\text { dikode }\end{array}$ \\
\hline Jur & nlah & 15 & & & 0 & 15 & \\
\hline
\end{tabular}

Keterangan:

T: Tepat TT: Tidak Tepat

\section{K ode tidak tepat Penyebab L uar Cedera} Dari 50 sampel dokumen rekam medis pasien rawat inap terdapat 41 penyebab luar cedera tidak di kode dan 9 diagnosis cedera yang tidak ditulis penyebab luarnya sehingga peneliti tidak dapat memverifikasi ketepatan kodenya. Berdasarkan hasil wawancara peneliti dengan petugas rekam medis bahwa kasus cedera tidak ditulis penyebab luarnya pada lembar anamnesa ataupun lembar instalasi gawat darurat karena faktor individu tenaga medis, sedangkan tidak di beri kode pada penyebabluar karena pengetahuan petugas terbatas di dalam melakukan kodefikasi.

J umlah petugas rekammedis hanya di bebankan kepada dua orang yang seharusnya dikerjakan oleh empat orang dan sebelumnya tidak ada SIR on line sehingga petugas koding Ialai dan tidak memprioritaskan kode penyebab Iuar tapi sekarang dengan adanya SIR on line, petugas merasa dituntut atau di ingatkan betapa pentingnya melaksanakan kodefikasi dengan tepat sebagai laporan morbi di tas dan mortal itas serta penghitungan berbagai angka statistik Rumah Sakit.

\section{PEMBAHASAN}

1. Tinjauan K etepatan K ode ICD-10 Diagnosis C edera Pasien

Hasil penelitianmenunjukkan bahwa kode diagnosis cedera yang tepat sebanyak 3 kode, sedangkan kode diagnosis cedera yang tidak tepat sebanyak47 kode dari 50 kode diagnosis cedera yang terdapat pada formulirringkasan masuk dan keluar.Kesalahan pada kodefikasi dari yang terbanyak sampai yang terkecil dari 50 kodediagnosis cedera dapat diuntkan yaitu; kesalahan pemilihan Blok sebanyak 16 kasus, digit ke-4 dan ke-5 terdapat 15 kasus, digit ke 5 ada 15 kasus dan kesalahan penetapan pemilihan Sub blok 2 kasus.

\section{a. Patah Tulang (F racture)}

Dari 22 jumlah kasus cedera patah tulang (fracture) tidak ada yang tepat.

1) Kesalahan dalampenetapan kodeBlok sebanyak 3 kode

a) Diagnosis utama pada ringkasan masuk dan keluar : fr. Clavicula dengan kodeS12.9

b) Kode sesuai aturan ICD-10 :fr. Clavicula ada pada Blok dan spesifikasiS42.00. 
Kode Blok S12.9 klasifikasi fraktur atau patah tul ang bagian leher sedangkan diagnosis kasusini dikel ompokkan pada Blok S42 beserta klasifikasi fraktur atau patah tulang pada bahu dan lengan atas, dengan kodeSubblok atau Subdivisi S42.0 dan jenis fraktur yaitu tertutup sehingga kodeakhir ' ${ }^{\prime} 0^{\prime}$ adalah $\$ 42.00$

2) Kesal ahan ada pada digit ke-5 sebanyak 15 kode salah satunya yaitu:

a) Diagnosis utama pada ringkasan masuk dan keluar : fr. Distal femur dengan kode $S 72.0$

b) Kodesesuai aturanICD-10 untuk fr. Distal femur adalah $\$ 72.00$

Digit ke 5 atau karakter tambahan pada kode diagnosis fraktur untuk menjelaskan jenis fraktur tertutup atau terbuka apabila kasus fraktur tidak dijelaskan tertutup atau terbuka maka diklasifikasi sebagai tertutup.

Word Health Organization Geneva volume I, (2004 :867)menyatakan "the following subdivisions are provided for optional use in a supplementary character position where it is not possible or not desired to use multiple coding to identify fracture and open wound; afracture not indicated as closed or should be classified as close".

0 closed

1 open

Artinya "Subdivisi berikut('.0' untuk fraktur tertutup dan '.1' untuk fraktur terbuka) disediakan untuk karakter tambahan, kalau penggunaan kode ganda fraktur dan luka terbuka tidak di inginkan.Fraktur yang tidak jelas tertutup atau terbuka harus diklasifikasi sebagai tertutup".

Berdasarkan catatanSub blok ini maka untuk kode diagnosis fraktur ini ditambahkan.' 0' pada digitke 5 sehigga kode yang tepat adalah $\$ 72.00$.

3) Kesalahan didigit ke-4 dan ke-5 se banyak 4 kode sal ah satunya a) Diagnosis utama pada ringkasan masuk dan keluar : fr. Froksimal humerus dextra dengan kodeS42

b) Kodesesuai aturan ICD-10 untuk fr. Froksimal humerus dextra : $\mathrm{S} 42.00$

Digit ke-4 untuk Sub blok S42 yaitu '.0' - '.9' kecuali ‘ .5,.6' fungsinya untuk mendapatkan kode fraktur yang lebih spesifik pada bagian bahu dan lengan atas (fracture pf shoulder and upper arm). Sedangkan digit ke-5 fungsinya untuk mendapatkan penjel asan tentang jenis fraktur tertur tup atau terbuka. (lihat catatan kasus a2).

4) Kesalahan karena diagnosis sekunder tidak dikode sebanyak 2 kasus, salah satunya yaitu:

a) Diagnosis utama pada ringkasan Masuk \& keluar : fr.alveolus + fr. Colles dengan kode S92.5

b) Kodesesuai aturan ICD-10untuk fr.alveolus + fr. Colles adalah $\mathrm{S} 02.80+\mathrm{S} 52.50$

Word Health Organization volumell, (2004:129)menyatakan yang artinya "Kalau terdapat cedera ganda atau multipel dan tidak ada yang di pilih sebagai “kondisi utama”(KU), maka kodelah mereka pada kategori yang tersedia untuk cedera ganda yang:

1. Sejenis, di derah tubuh yang sama: biasakarakter kempat' .7' pada S0-S99

2. Tidak sejenis, tapi di daærahtubuh yang sama: biasanya karakter keempat' .7' padakatagri terakhir setiap bl ok, seperti S09, S19, S29 dan seterusnya

3. Sejenis, pada daerah tubuh yang berbeda: pada T00-T05

a. Untuk cedera internal dengan cedera permukaan dan/ atau luka terbuka saja, pilih cederainternal sebagai 'KU'.

b. Unuk fraktur tengkorak dan tulang muka dengan cedera intrakranium, kode cedera intrakranium sebagai ' $\mathrm{KU}$ '. 
c. Untuk perdarahan intrakranium dengan cedera lain dikepala, kode perdarahan intrakranium sebagai ' $K U$ '.

d. Untuk fraktur dengan luka terbuka hanya dilokasi yang sama, kode fraktur sebagai 'KU'.

Jikadigunakan kategori cederaganda atau multipel, kode masing-masing cederabisadi pakai untuk kodetamba han. Pada kasus pengecualian di atas, di samping kode KU, cedera terkait bisa diidentifikasi baik dengan kode tambahan atau dengan angka yang disediakan untuk tujuan ini

Berdasarkan catatan tersebut karena kasus ini jenis cederanya sama yaitu sama-sama fraktur akan tetapi diba gian anggota tubuh yang berbeda maka harus dikode masing-masing.

5) Kesalahan pada digit ke-4 dan digit ke-5

a) Diagnosis utama pada ringkasan Masuk \& keluar : fr. Dento alveolus, rahang atas dengan kode $\mathrm{S} 02 . \underline{5}$

b) Kodesesuai aturan ICD-10 untuk fr. alveolus danrahang atasadalah S09.70 sebagai kode diagnosis utamasedangkan kodediagnosis sekunder atau tambahannya adalah kedua kode diagnosis fraktur yaitu:

1. fr. Alveolus dengan kode ICD; 10 S02.80 dan

2. $\mathrm{fr}$, rahang atas dengan kode ICD-10 S02.40.

J adi kalau terdapat cedera sejenis, di daerah tubuh yang sama maka kode diagnosisnya dijadikan satu, biasa karakter keempat ' .7' pada SO-S99 (WHO, 2004).

b. Cedera permukaan (Superficial injury)

Kode diagnosis cedera permukaan (Superficial Injury)tidak adayang tepat

1) Kesal ahan pada kode blok yai tu kode T30

a) Diagnosis utama pada ringkasan Masuk \& keluar: Combustion tingkat II tanganatas $9 \%$ badan $18 \%$ + dada dengan T30

b) Kode sesuai aturan ICD-10 Combustion tingkat II tangan atas $9 \%$ badan $18 \%$ +dadaadadi Sub bl okT00.8 sedangkan kode sekundernyaT23.2 Combustion tingkat II tangan atas (burn of second degree of wrist and hand) T21.2Combustiontingkat II badan $18 \%$ + dada (burn of second degree of trunk)

Kode Sub blok T30 untuk klasifikasi luka bakar dan korosi bagian tubuh yang tidak spesifik sedangkan klasifikasi diagnosis kasus ini sudah spesifik maka kode yang sesuai aturan ICD-10 adalah harus dikode berdasarkan situs atau luka bakar bagiantubuh masing-masing sebagai kode sekunder sedangkan untuk kondisi utamanya memakai kode multipel yaitu: T00.8. (lihat catatan kasus 24)

2) Kesalahan adapadadigit ke-4karena tidak ditulis

a) Diagnosis utamapadaringkasan masuk dan keluar :hematoma. dengan kodeT14

b) Kode sesuai aturan ICD-10 untuk hematoma. adal ah T14.0

Sub blok T14 klasifikasi cedera pada bagian tubuh yang tidak spesifik dan tipe klasifikasi cedera tidak ditentukan. Sedangkan diagnosis hematoma termasuk tipe klasifikasi cedera permukaan (superficial injury) Maka kode digit ke-4 dari T14 ini adalah ' .0' yang di pilih dari digit Ke-4 yang tersedia ('.0' - '.9' sehingga kode ahi mya adal ah T14.0 (WHO, 2004).

\section{c. L uka ter buka (open wound)}

Kodediagnosis cederalukaterbuka (open wound) yang tepat satu kode sedangkan yang tidak tepat dua kode.

1) Kesalahan dal am penetapan Blok

a) Diagnosis utamapadaringkasan masuk dan keluar : luka robek pada kepala, vulnus laceration dengan kodeS32.8 
b) Kode sesuai aturan ICD-10 luka robek pada kepala, vulnus laceration (Open wound of head, part unspecified ) ada pada kode Blok S01.9

Kode Blok S32.8 tipe klasifikasi cedera yaitu patah tulang (fracture) dibagian spinal lumbar dan pelvis sedangkan kasus ini tipe klasifikasi cedera luka robek pada kepala (laceration) yang tidak jelas sehingga kode Blok dan digit ke-4 yang sesuai dengan ICD-10 adalah S01.9.

2) Kesal ahan tidak menulis kode diagnosis sekunder

a) Diagnosis utama pada ringkasan masuk dan keluar : Iuka tusuk pada bahu dan luka bacok pada telapak tangan dengan kodeT14.6

b) Kode sesuai aturan ICD-10 luka tusuk pada bahu dan luka bacok pada telapak tangan (open wound of wrist and hand + open wound of shoul der) dengan kodeS61.9+ S41.0

Kode T14.6 klasifikasi injury of muscles and tendon yang tidak ditentukan sedangkan tipe klasifikasi cedera dan bagian tubuh sudah ditentukan.Kode S61.9 bagian lukaterbuka pergel angan tangan dan tangan yang tidak dijelaskan dan kodeS41.0 bagianlukaterbuka bahu.

Pada kasus ini terdapat dua diagnosis cedera di bagian tubuh yang berbeda dengan jenis cedera yang sama yaitu luka tusuk, maka masing-masing diagnosis harus dikode (WHO, 2004).

\section{d. Internal injury}

Kode diagnosis cedera organ bagian dal am (internal injury)tidak adayang tepat

1) Kesalahan di Sub kategori digit ke-5 yaitu;

a) Diagnosis utama pada ringkasan masuk dan keluar : CKR (Cedera Kepala Ringan) dengan kode S06.0

b) Kodesesuai aturanICD-10Cedera KepalaRingan/CKR (concussion, commotion cerebri)adalah $\mathrm{S06.00}$
Word Health Organization Geneva, 2004 vol ume 1 hal .870 :menyatakan "the following subdivisions are provided for optional usein a supplementary character position whereit is not possibleor notdesired to usemultiple coding to identify intracranial injury and opend wound:

0 withoutopen intracranial wound

1 with open intracranial wound

Artinya "subdivisi berikut disediakan untuk karakter tambahan kal au penggunaan kode ganda tidak diinginkan untuk identifikasi cedera dan luka terbuka intrakranium" Maksud dari catatan sub blok ini adalah koder disarankan untuk mengikutsertakan karakter tambahan (supplementary character) yaitu angka '. 0 ' tanpaluka terbuka intrakranium dan angka '.1' dengan luka terbuka intrakranium. Makakodeyangsesuai denganaturan ICD -10 adalah S06.00.

2) kesalahan didigitke-4danke-5 sebanyak tujuh kode

a) Diagnosis utama pada ringkasan masuk dan keluar: CKR (Cedera Kepala Ringan) dengan kode S06

b) Kode sesuai aturan ICD-10 Cedera Kepal a Ringan/CKR (concussion, commotion cerebri) adalah $\mathrm{S06.00}$

Digit ke-4 untuk Sub blok S06. yaitu '.0' - '.9' fungsinya untuk mendapatkan kode jenis cedera yang lebih spesifik pada bagian dalam kepala (berdasarkan tingkat keparahan). Sedangkan digit ke-5yaitu fungsinya untuk mendapatkan penjelasan tentang jenis cedera bagian dalamkepala luka terbuka atau ti dak.

3) Kesal ahan milihan sub blok dan diagnosis sekunder tidak dikode

a) Diagnosis utama pada ringkasan masuk dan keluar: CKR (Cedera KepalaRingan) +fractureorbita dengan kode S02.4

b) Kode sesuai aturan ICD-10 CKR/Cedera Kepala Ringan (concussion, commotion cerebri) + fracture orbita adalah S09.7 
sebagai kondisi utama dan kode diagnosis sekunder: $\mathrm{S} 06.00+$ S02.80

Kode Sub blok S02.4 klasifikasi fraktur tulang-tulang rahang bawah (fracture of malar and maxillary bones) sedangkan diagnosis CKR adalah cedera intrakranial berada di Sub blok S06 dan fr. Orbit berada di Sub blok dengan spsifikasiya S02.8 karena terdapat cedera yang berbeda tapi berada dilokasi yang sama maka maka digit ke-4 atau karakter keempatnnya .7 pada ahir kategori blok: S09, S19, S09 dan seterusnya maka kode ahi mya adalah S09.7 dan yang menjadi kondisi utamanya adalah cederaintrakranial bukanfraktur.(lihat catatan kasus 24)

4) Kesal ahan di di git ke-4 dan ke-5 dengan diagnosis sekunder tidak dikode dapat diuraikan sebagai berikut;

a) Diagnosis utama pada ringkasan masuk dan keluar : CKS (Cedera Kepala sedang) + fr. Femur dengan kode 506

b) Kodesesuai aturan ICD-10CKS + fr. Femur adalah S06.20 + $\mathrm{S} 72.90$

Kode S06 cedera intrakranial yang beum jelas karena digit ke-4 dan ke-5 bel um terisi sedangkan diagnosis CKS (Cedera Kepala sedang) berada di Sub blok dan spesifikasinya S06.20 dan fr. Femur ataupatah tulang pada pinggul dikelompokkan pada Sub bl ok S72 bagian fraktur femur tidak ditentukan dan jenis frakturnya tidak disebutkan tertutup atau terbuka sehingga kode ahi r adal ah S72.90 sedangkan yang menjadi kondisi utamnya adalah kode CKS S06.20. (lihat catatan kasus 24)

Pada kasus cedera ini salah karena digit Ke-4 tidak ditulis dengan kode yang sediakan yaitu '.0' - 9.Fungsi digit ke-4 pada kasus cedera ini untuk mengetahui jenis cedera (tingkat keparahan) bagian dalam kepala yang lebih spesifik sedangkan digit ke 5 fungsinya untuk mengetahui bagian dalam kepala disertai luka terbuka atau tidak (WHO, 2004).

\section{e. Dislokasi}

Kodediagnosiscederakasusdislokasi yang tepat 2 kode sedangkan yang tidak tepat 6 kode, pemberian kodetidaktepat ada pada:

1) Kesalahan kode blok sebanyak lima kode
a) Diagnosis utama pada ringkasan masuk dan keluar : dislokasi dengan kode S63
b) Kode sesuai aturan ICD-10 dislokasi ada di Blok T14.3

Kode Sub blok S63 dislokasi, terkilir sendi dan ligament pada pergelangan tangan dan tangan sedangkan kasusini dislokasi yang tidak dijelaskan maka berada di Sub blok T14 sehingga kode yang tepat sesuai ICD-10 adalahT14.3

2) Kesalahan didigit ke-4
a) Diagnosis utama pada ringkasan masuk dan keluar : dislokasi el bow dengan kodeS53.4
b) Kode sesuai aturan ICD-10 dislokasi elbow adalah S53.1

KodeS53.4 sprain and strain of el bow artinya si ku terkilir sedangkan dislokasi elbow kodenya S53.1.

3) Kesalahan pada Sub blok yaitu kode S92.1
a) Diagnosis utama pada ringkasan masuk dan keluar : dislokasi talus, dislokasi ankledengan kode S92.1
b) Kode sesuai aturan ICD-10 dislokasi talus,dislokasi ankle ada pada Su blok S93.0

Kode S92.1 klasifikasi patah tulang (fracture) pada talus sedangkan pada kasus dislokasi ada diSub blok S93khususnya dislokasi talus, dislokasi ankle maka di git ke-4 adal ah ' .0’ sehingga kode akhir adalah S93.0. pada kasus ini terdapat dua jenis cedera yang sama dan di anggota ba gian tubuh yang sama maka kodesatu sajayang mewakili keduanya (WHO, 2004). 


\section{KodeT idak Tepat Berdasarkan ICD-10 pada Penyebab L uar Cedera Pasien}

Kode penyebab Iuar cedera dapat diidentifikasikan menjadi kode yang tepat dan tidak tepat.Kode tepat adalah penetapan kode penyebab luar yang sesuai ICD-10 berdasarkan diagnosis diformulirringkasan masuk dan keluar.Sedangkan kode tidak tepat adalah penetapan kode diagnosis tidak sesuai dengan aturan pengodean ICD-10.

Word Health Organization volume 1 (2004) menyatakan yang artinya "Kode dari Bab ini digunakan untuk tambahan pada kode dari bab lain yang menunjukan bentuk kondisi, yang sering diklasifikasikan pada Bab XIX ( cedera, keracunan dan konsekuensi tertentu tertentulain penyebab luar S00 - T98). Penyebab kematian sebaiknya dikode menurut Bab XIX dan XX, tapi kalau hanya satu kode yang ditabulasikan maka kode dari Bab XX yang diutamakan. Kondisi lain yang dapat dinyatakan sebagai akibat penyebab luar diklasfikasikan pada Bab I - XVIII. Untuk kondisi ini, kodedari BabXX hanya digunakan untuk informasi tambahan pada analisis kondisi ganda" (WHO, 2004).

Hasil penelitianmenunjukkan bahwa kode penyebab luar cedera pasien rawat inap dari 50 sampel dokumen rekam medis terdapat 41 penyebab luar cedera tidak dikode dan 9 diagnosis cedera yang tidak ditulis penyebab luarnya sehingga peneliti ti dak dapat memverifikasi ketepatan kodenya.

Berdasarkan hasil wawancara peneliti dengan petugas rekammedis bahwa kasus cederatidak ditul is penyebab luarnya pada lembar anamnesa ataupun lembar instalasi gawat darurat karena faktor individu tenaga medis.Sedangkan tidak diberi kode pada penyebab luar cedera karena; petugas yang melakukan kodefikasi bukan lulusan perekam medis, jumlah petugas rekam medis hanya dibebankan kepada 2 orang yang seharusnya dikerjakan oleh 4 orang dan sebelumnyatidak ada (Sistem I nformasi Rumah Sakit) SIR on line sehingga petugas koding Ialai dantidak memprioritaskan kodepenyebab Iuar tapi sekarang dengan adanya SIR on line, petugas merasa dituntut atau diingatkan betapa pentingnya melaksanakan kodefikasi dengan tepatsebagai laporan morbidi tas dan mortal itas serta penghitungan berbagai angka statistik Rumah Sakit.

\section{SIM PULAN}

Pengisian kode pada di agnosis cedera dan penyebab Iuar cedera (external causes) berdasarkan ICD10 pada pasien masih terdapat kesalahan dalam penulisan kode. Faktor penyebab tidak tepat proses kodefikasi pada berkas rekam medis karena masih minim kuantitas dan kualitas sumber daya manusia dengan bidang keilmuan adalah rekam medis dan informasi kesehatan.

\section{DAFTAR PUSTAKA}

Budi, S.C. 2011. Manajemen Unit Kerja Rekam Medis. Yogyakarta: QuantumSinergi Media.

Keputusan Menteri Kesehatan RI. 2007. Buku Panduan Penentuan Kode Penyebab Kematianm Menurut ICD-10. J akarta: PenerbitBadan Penelitian dan Pengembangan Kesehatan.

Keputusan Menteri Kesehatan RI Nomor 377/ Menkes/III/2007.Tentang Standar Profesi Perekam Medis Dan Informasi Kesehatan. Jakarta: Menkes.

Peraturan Menteri Kesehatan RI . 2008. Nomor.269/ Menkes/Per/III/2008. Tentang RekamMedis. Jakarta: Menkes.

Riyadina, W. dan Subik, I.P. 2007.Profil Keparahan Cedera Pada Korban Kecelakaan Sepeda Motor Di Instalasi Gawat darurat RSUP Fatmawati 2007. Jumal Universa Medicina, 26(2): 64-72.

Rustiyanto,E. 2011.Etika Profesi Perekam Medis dan Informasi Kesehatan. Yogyakarta: Graha IImu.

Silaen, S. danWidiyono.2013. Metodelogi Penelitian Sosial Untuk Penulisan Skripsi Dan Tesis. Jakarta: IN MEDIA.

World Heal th Organization. 2004. International Statistical Classfication of diseases and Related Health Problems Tenth Revision, Violume I,II dan III. Geneva: WHO. 